\title{
Explicit reading strategy instruction or daily use of strategies? Studying the teaching of reading comprehension through naturalistic classroom observation in English L2
}

\section{Lisbeth M. Brevik ${ }^{1}$ (1)}

Published online: 7 May 2019

(c) The Author(s) 2019

\begin{abstract}
Research suggests that developing deep understanding of text requires sustained emphasis on reading comprehension instruction and scaffolded strategy practices. However, although research has shown explicit teaching of reading comprehension strategies to be effective, we know little about whether strategy instruction and use are part of "daily life" in classrooms (Pearson, \& Cervetti, 2017). The present study analyses 60 video recorded English as a second language (L2) lessons in seven lower secondary schools in Norway, across two school years (9th and 10th grade) based on The Protocol for Language Arts Teaching Observation. The article investigates the types of text-based reading comprehension instruction and strategy use that goes on in these classrooms. Key findings show that teachers engage their students in reading comprehension instruction of narrative and expository texts more than half the time, offering guided strategy practice based on student needs, and encouraging daily use of known reading comprehension strategies, instead of explicitly teaching new ones. These are powerful examples of successful reading comprehension instruction, and show that when English teachers prioritise reading comprehension instruction, they use authentic L2 texts to develop and scaffold critical literacy and metadiscursive awareness.
\end{abstract}

Keywords Reading comprehension - Reading strategy instruction · Video analyses · Close reading 


\section{Introduction}

Reading comprehension, a hallmark of effective and sophisticated reading instruction, is key to active participation in today's changing global society (Israeli, 2017; UNESCO, 2004; World Bank, 2013). Our understanding of the multi-layered nature of text environments, and the demands of virtual reality, has grown over the past decades, influencing our view of what it means to teach reading (Pearson, \& Cervetti, 2017). As reading comprehension is a complex, multidimensional interaction between reader, text, activity, and context, we have come to understand that developing reading comprehension requires a supportive classroom context to encourage strategic reading (Afflerbach, Pearson, \& Paris, 2017; Brevik, 2015; Brown, 2017; Kamil, Afflerbach, Pearson, \& Moje, 2011). Understanding various instructional pathways in classrooms is key to understanding how students develop as strategic readers, attending to how the teaching of strategies fits naturally with other components of reading comprehension instruction (Brown, 2017; Israeli, 2017).

Over the last decades, reading strategy instruction has been given considerable attention (Brown, 2017; Grabe, 2009; Koda, 2007; McNeil, 2011; Pearson, \& Cervetti, 2017; Pressley, 2008). However, most of this research concerns reading in the first language (L1), while comparatively little research examines second language (L2) classroom instruction (Brevik, 2015; Brown, 2017), which is worrying considering the diverse student population. Moreover, while most reading research focuses on younger readers or college students, less is known about comprehension strategies that students in secondary school employ to empower them to construct meaning from complex texts (Brown, 2017). This article is a contribution to redressing this situation by following secondary students over two school years (grades 9-10).

This situation underscores the crucial role teachers have in students' reading comprehension development, and the high expectations on teachers to address strategic reading in their teaching practices (Israeli, 2017; Hilden, \& Pressley, 2007) as well as teachers' beliefs that strategies should be explicitly instructed (Boardman, Boelé, \& Klingner, 2017). Although a robust research base points to benefits of explicit teaching of comprehension strategies for English monolinguals (National Institute of Child Health and Human Development [NICHD], 2000), a meta-analysis on the effects of explicit comprehension instruction found that L1 learners with limited language proficiency did not profit from explicit strategy instruction (Taylor, Stevens, \& Asher, 2006). Research on L2 readers also suggests that explicit strategy instruction is problematic, showing a negligible impact on their reading comprehension (August, \& Shanahan, 2006). Brown (2017) argued that explicit instruction is not necessarily effective for L2 learners due to their developing L2 competence, while collaborative strategy use has been more conducive to their needs, for example interventions where L2 readers engaged in strategic peer discussions and used strategies collaboratively (Klingner, \& Vaughn, 1996). In line with this view, Pearson and Cervetti (2017) argued that "the Achilles heel for strategy instruction [...] is finding a way to make it 
a part of "daily life"” (p. 35). Thus, more insight is needed concerning how to sustain strategies instruction beyond initial explaining, modelling and scaffolding, so that students maintain and transfer what they have learned across contexts and languages (Aukerman, Brown, Mokthari, Valencia, \& Palincsar, 2015; Grabe, 2009; Koda, 2007).

There is a need for systematic investigation not only of secondary L2 readers' understanding of written texts, but also what kind of scaffolded reading comprehension that takes place when comprehension instruction is prioritised in secondary L2 classrooms, and even more importantly, whether there is evidence of explicit reading strategy instruction or daily use of strategies in these L2 classrooms; daily use refers to strategies commonly used within a classroom as part of that class's strategy repertoire. In contrast to many previous studies, this study is not based on interventions or self-reports; instead, it is based on video recordings of "naturally occurring instruction" (Hassan, Macaro, Nye, Smith, \& Vanderplank, 2005) by following adolescents in L2 classrooms at seven lower secondary schools across two school years. The main analytical focus is on how teachers frame reading comprehension strategy instruction; aiming to provide new, nuanced insight into how L2 reading comprehension is instructed, scaffolded, and framed in actual classrooms in secondary school settings.

\section{The Norwegian context}

All Norwegian children have a legal right to 13 years of free education beginning at age 6. The school system is divided into primary (grades 1-7), lower secondary (grades 8-10), and upper secondary school (grades 11-13). The study followed the same students over two school years (grades 9-10); the two final years of lower secondary school (ages 13-15). At the beginning of grades 8 and 9, students participate in national reading tests. The end of grade 10 constitutes national exams, where students are provided relevant texts in advance, which they are expected to read as preparation. English is the L2 subject, and mandatory in grades 1-11, with approximately two lessons per week in lower secondary school.

The English subject curriculum focuses on context-specific strategies through various genres, reflecting the high level of proficiency among Norwegian learners of English. Investigating reading instruction in Norway is relevant as the national curriculum has defined reading as a "key competence" since 2006, mandated as an integral part of all subjects (Hertzberg, \& Roe, 2016). Teachers must stimulate students as readers by including reading strategies in their instruction, emphasising that "the reading of texts on screen and paper is a prerequisite for lifelong learning and for active participation in civic life" (Norwegian Directorate of Education and Research, 2012, p. 8) and the importance of the before reading phase to enable students to use their knowledge, "to get an overview of the text prior to reading" (p. 9). However, little is known about what happens when students read for understanding in the classroom (Aasen et al., 2012). Although a few studies have identified reading comprehension strategy instruction and use in Norwegian in lower secondary 
school (e.g. Anmarkrud, 2009; Anmarkrud, \& Bråten, 2012; Bråten, \& Anmarkrud, 2013; Magnusson, Roe, \& Blikstad-Balas, 2018), and in English in upper secondary school (Brevik, 2014, 2017; Brevik, \& Hellekjær, 2018), few studies have examined comprehension instruction in English L2 lessons in lower secondary school.

\section{Reading comprehension strategy instruction}

Strategies is a complex concept in need of clarification. Landmark studies argue that these complexities include conceptual differences between skills and strategies and between strategic reading and activities (Afflerbach, Pearson, \& Paris, 2017; Cohen, 2011; Grabe, 2009; Pressley, 2008; Hilden, \& Pressley, 2007; RAND, 2002). While skills relate to the reader's automatic responses to text; strategies comprise the reader's awareness of comprehension problems and selection of the most appropriate tool to solve the problems, and is the engine that drives comprehension. Activities involve the reader's interaction with text, in which comprehension might be part, while strategic reading is a goal-oriented process that involves conscious strategy use to overcome reading-related obstacles, in terms of what the reader does to construct meaning. Scholars have emphasised that strategies "can be organized taxonomically according to strategies applied before, during, or after reading, but the recursive nature of looking forward and backward through text while reading allows similar strategies to be applied at different times" (Paris, Wasik, \& Turner, 1991, p. 611). Discussions based on this perspective has argued that the strategic actions readers might take, enhances reading comprehension, such as activating prior knowledge before reading, predicting and monitoring comprehension during reading, and summarizing texts after reading (Duke \& Pearson, 2002; Duke et al., 2011; Paris et al., 1991). Although this literature contributes with invaluable knowledge about strategic reading, few studies investigate how these approaches are reflected in natural secondary classroom settings.

Reviews in the field of reading comprehension strategy instruction can be divided into interventions and observations. While the majority of studies have focused on the effectiveness of strategy instruction (Boardman et al., 2017; Meyer, Wijekumar, \& Lei, 2018; Plonsky, 2011), classroom observation remains an understudied area (Pearson, \& Cervetti, 2017). Since the 1980s, interventions have commonly evaluated competing strategy instruction programmes; favouring explicit teaching of comprehension strategies, and demonstrating that learning to apply strategies to text improved students' reading comprehension (NICHD, 2000; Palinscar, \& Brown, 1984). Observation studies have attempted to describe reading comprehension as represented by classroom practices, while showing little evidence of direct instruction of comprehension, let alone evidence of students' independent strategy use (Pearson, \& Cervetti, 2017; Pressley, 2008).

The recommended reading comprehension strategies vary. Intervention studies have found a set of strategies to be effective; for example, the reciprocal teaching strategies (i.e., predicting, summarizing, clarifying, and questioning; Palincsar, \& Brown, 1984), and strategies identified by the US National Reading Panel (i.e., comprehension monitoring, cooperative learning, graphic organisers, story structure, 
question answering, question generation, and summarisation; NICHD, 2000). Other recommended reading strategies are also found worth teaching to improve reading comprehension (i.e., setting purposes; previewing and predicting; monitoring, clarifying, and fixing; visualizing; and drawing inferences; Duke, Pearson, Strachan, \& Billman, 2011; Grabe, 2009). Questions remain concerning the effectiveness of teaching single or multiple strategies readers can select, depending on the text and their comprehension problem (Wilkinson, \& Son, 2011), and researchers have asserted this concern is more critical than which strategies to teach, considering the relative ease of explicitly teaching a strategy versus prompting flexible and independent daily use of strategies (Pearson, \& Cervetti, 2017).

Strategy instruction might also be a matter of grain size. Instead of focusing on discrete strategies, we might consider frameworks based on reading purpose. One such framework is the constructively responsive reading comprehension strategies (Pressley, \& Afflerbach, 1995), originally related to print-based reading; meaning making, self-monitoring, information evaluation, and recently expanded to include Internet strategies; text location (Cho, \& Afflerbach, 2017). Cho and Afflerbach (2017) argued that although the same strategies can be used with print-based and online texts, there is a need for discrete strategies to support comprehension with complex, digital text environments.

The most frequently cited model of comprehension strategy instruction is the gradual release of responsibility (Pearson, \& Gallagher, 1983). Consistently supported by research since the 1980s (McVee et al., 2018), teachers gradually release responsibility for strategy use to students. The teacher is responsible for explaining and modelling strategies. Shared responsibility is characterised by guided practice through scaffolding strategy use. Finally, the region of student responsibility proceeds with reducing teacher scaffolding, featuring independent student practice (Pearson, \& Gallagher, 1983). Across these practices, scaffolding principles apply based on student needs; fading scaffolding over time and varying scaffolding within and across lessons and between students (McVee et al., 2018).

\section{Theoretical perspectives}

This article's perspective is that the development of reading comprehension requires scaffolding in the classroom, which is closely related to a sociocultural view of learning as a social process embedded in broader contextual practices. For 50 years, successful reading comprehension has been framed by a combination of three factors (reader, text, and context), and each has been seen as the leading explanation. Based on research since the 1970s, the RAND Reading Panel defined reading comprehension as "the process of simultaneously extracting and constructing meaning through interaction and involvement with written language" (RAND, 2002, p. 11), which emphasises the critical position of the text (extracting meaning) and the reader (constructing meaning), as well as the sociocultural context; extending across disciplines, to physical contexts (school, work, or home), and the reading activity.

Since reading comprehension can be observed only indirectly, its complexity is difficult to ascertain (Israeli, 2017; Koda, 2007), making the teaching and prompting 
of reading strategies only one aspect of effective comprehension instruction (Brown, 2017). Duke et al. (2011, p. 58) noted ten "essential elements" of such instruction. These are building disciplinary and world knowledge; providing exposure to a volume and range of texts; providing motivating texts and contexts for reading; teaching strategies for comprehending; teaching text structures; engaging students in discussion; building vocabulary and language knowledge; integrating reading and writing; observing and assessing; and differentiating instruction. These essential elements align with Catterson and Pearson (2017), who argued that close reading instruction might be worthwhile to more fully account for interactions among the reader, text, activity, and sociocultural context during the reading process. Tracing key theories of close reading through the past 75 years, they suggested five classroom practices to promote the thoughtful interrogation of text; including background knowledge; authentic reading and writing; metadiscursive awareness; critical literacy; and dialogically organised discussion. Authentic reading is here understood as the reading of textual types that occur outside of a learning-to-read context along with reading those texts for their intended purposes (Catterson, \& Pearson, 2017).

These processes are particularly relevant in classroom contexts, as the field of reading comprehension "has witnessed an increased realisation that cognitive variables interact with social and cultural variables in complex ways, necessitating the use of more complex methods of data collection" (Kamil et al., 2011, p. xviii). Literature in the field of L2 reading comprehension stress the need to conduct more qualitative studies on strategies-based practices that go beyond description and selfreported data and instead yield rigorous interpretation and explanation, including contextual factors (Brown, 2017; Cohen, 2011). Since few studies have followed teachers and classrooms beyond the completion of interventions, little is known about the persistence of strategy use and instruction over time. Suggested options include multiple measures of "coded observations (using pre-existing or constructed schemes)" (Brown, 2017, p. 560), which the present study does, using video recordings to identify detailed patterns in reading comprehension practices across two school years.

\section{Methods}

This study is part of the large-scale video study Linking Instruction and Student Experiences (LISE). During the 2015-16 and 2016-17 school years, the research team (including several research assistants) collected video-recordings among six school subjects in seven lower secondary schools. The sampling was based on a prior study, which included 49 schools in 8th grade (Klette, Blikstad-Balas, \& Roe, 2017). We sampled seven schools (Schools 2, 7, 9, 13, 17, 50, 51) for variation in levels of student achievement, based on high $(n=2)$, average $(n=2)$ and below average $(n=2)^{1}$ gains on the national reading tests from 8 th to 9 th grade, as well as demographic and geographic variation across three school districts, i.e.

\footnotetext{
${ }^{1}$ Missing information about gains in the seventh school.
} 


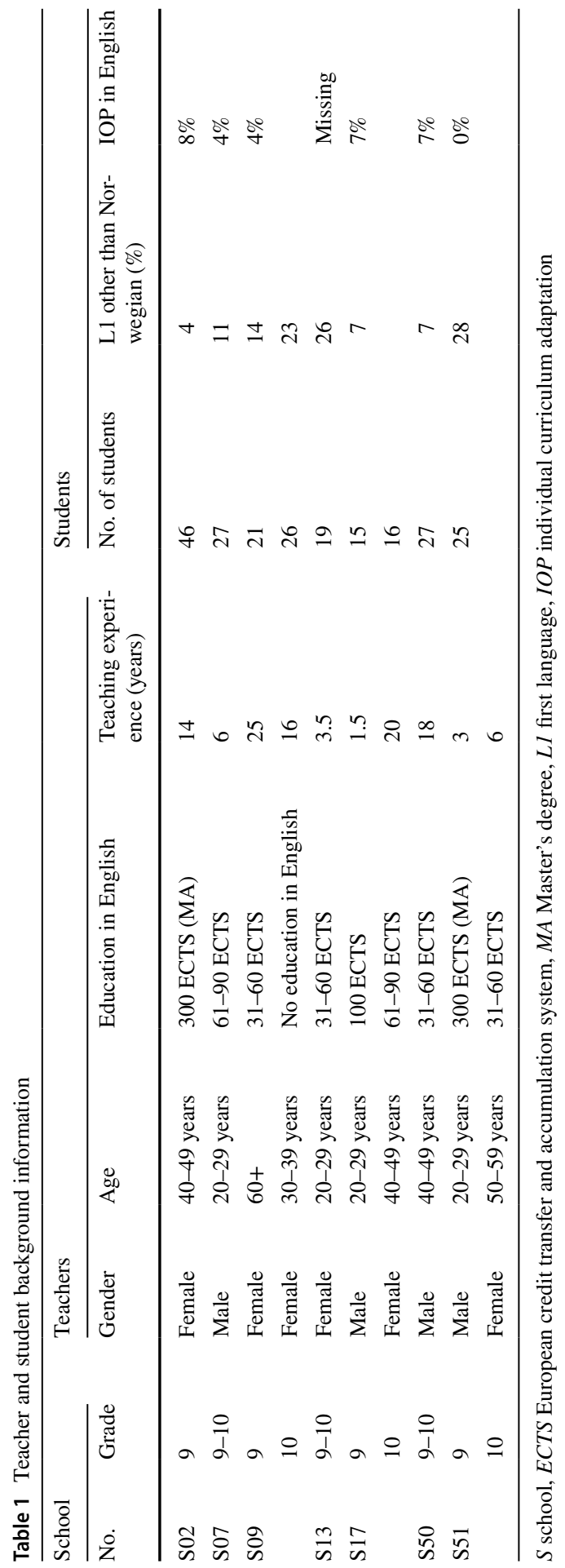




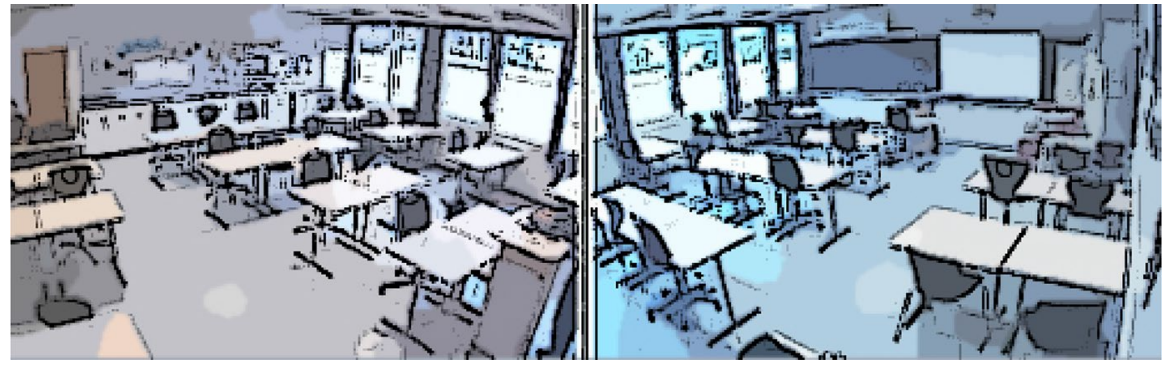

Fig. 1 Camera views (one facing the students and one facing the teacher)

Table 2 Video-recorded English L2 Lessons $(\mathrm{N}=60)$

\begin{tabular}{lllllllll}
\hline Grade & S02* & S07 & S09 & S13 & S17 & S50 & S51 & Total \\
\hline 9th & 6 & 4 & 6 & 4 & 4 & 5 & 4 & 33 \\
10th & 0 & 4 & 5 & 4 & 5 & 5 & 4 & 27 \\
\hline
\end{tabular}

*S02 withdrew from participation in 10th grade

urban $(n=2)$, suburban $(n=3)$, and rural $(n=2)$ schools, in areas characterised by low $(n=1)$, medium $(n=3)$ and high $(n=3)$ socioeconomic status. For teacher and student background variables, see Table 1.

Table 1 shows that few students moved between schools; there were no new students in the observed classrooms in grade 9, whereas in grade 10, five new students started in S09, one in S17, and two in S50. The proportion of students who had different first languages from Norwegian varied between 4 and 26\%, and a small proportion of students required specialist support to access the English curriculum (4-8\%).

\section{Video-recorded lessons}

Video recordings are valuable in analyses of classroom instruction, due to the possibility of detailed and systematic investigation of complex situations. The design relied on two cameras simultaneously recording the same lesson. One small, wallmounted camera at the back of the classroom faced the teacher, and the other at the front faced the classroom. Two microphones were used, one on the teacher and one fixed to capture students (Klette et al., 2017). This design provided reasonably good video and audio recording of whole-class discourse and student interactions (Fig. 1).

Each classroom was observed for 4-6 lessons each year, totalling 60 English lessons (Table 2). The frequency of observations was designed to maximise the likelihood of reliable estimates of teacher practice, based on earlier generalisability studies of the observation tool (Cohen, Schuldt, Brown, \& Grossman, 2016). The video-recorded lessons identified reading practices, including what was read, how 
much time they spent reading, and reading strategies. We also observed whether teachers instructed new strategies in the absence of text.

\section{Time-stamping analysis}

Using the video analysis programme InterAct, a trained master's level research assistant time-stamped all video-filmed reading activities. Three genre categories were used; authentic narratives (short stories, poems, lyrics, plays, novels, video clips, audio clips), authentic informational texts (historical documents, animations, web-based information), and non-authentic texts (textbooks). In addition, reading phases were assigned as follows: Before reading comprises sequences when the teacher referred to, or students prepared for reading a specific text. During reading comprises text-based reading sequences, including silent reading, reading aloud, and listening to audio or video adaptations of a text they had previously read or were reading. After reading comprises sequences after a text was read, where students worked with the text in question by doing text-based tasks or discussing the text. Sequences where students continued working with the same topic but not the text were not included. To ensure high levels of ongoing interrater agreement ( $\geq 80 \%$ exact-score agreement; Cohen et al., 2016), all analyses were validated in the research team, which resulted in agreement for $82 \%$ of the analyses, and all analyses without initial exact-score agreement were discussed until agreement was reached. 47 English lessons that concerned text-based reading instruction according to the above categories were identified, which were included in this study.

\section{Protocol for language arts teaching observation (PLATO) analysis}

Next, a systematic overview of the 47 text-based reading lessons was obtained using the PLATO 5.0 observation manual (Grossman, 2010; Grossman, Loeb, Cohen, \& Wycoff, 2013). PLATO is designed to assess quality aspects of English teaching, as the theory underlying PLATO articulates "the critical role of teachers in providing instructional scaffolding for students to help them succeed" (Cohen, \& Grossman, 2016, p. 310). PLATO consists of 13 elements representing effective teaching in secondary language arts education, two of which are important to this study; Text-Based Instruction (TBI) and Strategy Use and Instruction (SUI). Figure 2 provides an overview of the scoring (Grossman et al., 2013).

$T B I$. The subcategory use of authentic texts was developed to capture "when the teacher requires to interact with authentic text for a sustained period of time in order to build a deeper understanding of the text, the genre, and the reading process" (PLATO). According to PLATO, authentic texts are not made for teaching purposes (Cohen, \& Grossman, 2016) and can include published material, such as pieces of music, art, or film/video used for an English Language Arts 


\begin{tabular}{|c|c|c|c|c|}
\hline & Score 1 & Score 2 & Score 3 & Score 4 \\
\hline $\begin{array}{l}\text { TBI } \\
\text { reading }\end{array}$ & $\begin{array}{l}\text { There are no } \\
\text { authentic texts } \\
\text { present, or an } \\
\text { authentic text is } \\
\text { present but students } \\
\text { are rarely asked to } \\
\text { make use of it. } \\
\text { Reading silently } \\
\text { without a particular } \\
\text { task at hand, or } \\
\text { reading aloud } \\
\text { without } \\
\text { contextualisation }\end{array}$ & $\begin{array}{l}\text { Teacher provides } \\
\text { instructional activities or } \\
\text { opportunity for } \\
\text { discussion that require } \\
\text { students to refer to } \\
\text { authentic texts. } \\
\text { References to the text, } \\
\text { when they occur, focus } \\
\text { on recall of specific } \\
\text { details and do not } \\
\text { contribute to a broader } \\
\text { understanding of the } \\
\text { text. }\end{array}$ & $\begin{array}{l}\text { Teacher provides } \\
\text { instructional } \\
\text { activities or } \\
\text { opportunities for } \\
\text { discussion that } \\
\text { require students to } \\
\text { actively use authentic } \\
\text { texts. } \\
\text { Students are required } \\
\text { to cite specific } \\
\text { features or evidence } \\
\text { in order to construct } \\
\text { an understanding of } \\
\text { the text. }\end{array}$ & $\begin{array}{l}\text { Teacher provides } \\
\text { instructional activities or } \\
\text { opportunities for } \\
\text { discussion that require } \\
\text { students to actively use } \\
\text { authentic texts for a } \\
\text { sustained period of time. } \\
\text { Students are required to } \\
\text { cite and analyse specific } \\
\text { features of the text to build } \\
\text { a deeper understanding of } \\
\text { the text and often the genre } \\
\text { and how to approach texts } \\
\text { in general. }\end{array}$ \\
\hline $\begin{array}{l}\text { SUI } \\
\text { reading }\end{array}$ & $\begin{array}{l}\text { Teacher does not } \\
\text { refer to or provide } \\
\text { instruction about } \\
\text { strategies. This } \\
\text { includes referring } \\
\text { to strategies } \\
\text { without discussion } \\
\text { of why or when to } \\
\text { use them. }\end{array}$ & $\begin{array}{l}\text { Teacher introduces or } \\
\text { refers to at least one } \\
\text { strategy including why } \\
\text { (or how) to use it; } \\
\text { however, the teacher } \\
\text { does not provide explicit } \\
\text { instruction on how to } \\
\text { use the strategy. } \\
\text { Or the teacher prompts } \\
\text { student to use strategies, } \\
\text { and there is evidence } \\
\text { that students use them. }\end{array}$ & $\begin{array}{l}\text { Teacher provides } \\
\text { explicit, but limited, } \\
\text { instruction about a } \\
\text { strategy, including } \\
\text { how to use it. }\end{array}$ & $\begin{array}{l}\text { Teacher provides explicit } \\
\text { and detailed instruction } \\
\text { about one or more } \\
\text { strategies, including how } \\
\text { (and often why or when) to } \\
\text { use them. }\end{array}$ \\
\hline
\end{tabular}

Fig. 2 Overview of the categories describing Text-Based Instruction (TBI) and Strategy Use and Instruction (SUI), related to reading comprehension (PLATO 5.0)

(ELA) purpose. Thus, non-authentic texts are made specifically for classroom instruction.

SUI. Since SUI captures all ELA-related strategies (writing, speaking, listening, reading, and engaging with literature) "that can be used flexibly to apply to tasks in the current lesson as well as in the future" (PLATO), only the two latter sub-categories are included in this study. A key consideration is the difference between strategy prompting, when teachers suggest students use a strategy, without explaining how to complete it (Score 2), and strategy instruction, when the teacher explains how to apply a strategy, through modelling or guiding (Score 3).

Following the PLATO protocol, the 47 reading lessons were divided into 15-minute segments $(N=130)$. Each segment was scored $(1-4)$ based on evidence of TBI and SUI: Almost no evidence (Score 1), limited evidence (Score 2), evidence with some weaknesses (Score 3), or consistent strong evidence (Score 4) of text-based reading instruction or strategy use and instruction. Six certified PLATO raters, including the author, scored the video-recorded lessons. Using a validated coding manual allows for comparability and reduces the risk of personal interpretations of high-inference concepts (Klette et al., 2017). 


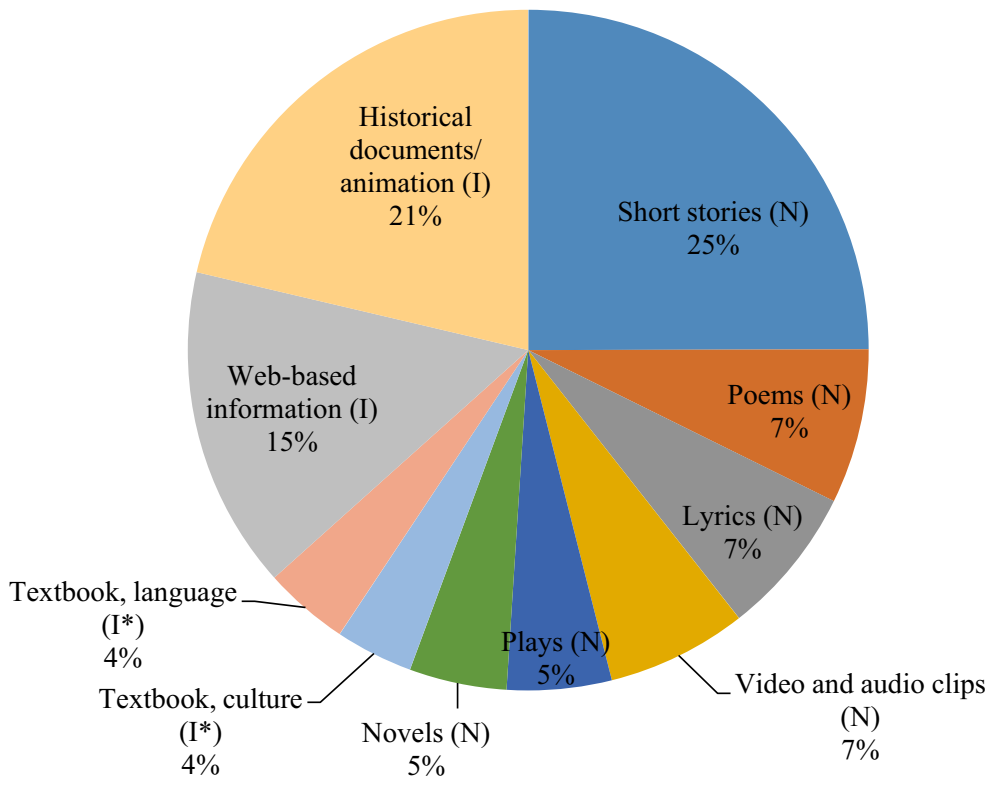

Fig. 3 Written and multimedia texts $(\mathrm{N}=$ narrative; $\mathrm{I}=$ informational) used in 47 out of 60 English L2 lessons. Note: $*$ non-authentic

\section{Research ethics and limitations}

Following the ethical guidelines of the Norwegian Center for Research Data (2006), written informed consent was provided by all teachers, students, and parents. A possible limitation is that the design will not capture students' comprehension problems or strategy use, unless verbally commented. However, since this study is concerned with reading comprehension and strategy use during naturalistic reading instruction, the design should provide useful and sought-after longitudinal data.

\section{Findings}

The findings indicate two main patterns. First, reading instruction occurred across the classrooms, ranging from authentic reading and use of background knowledge, to developing metadiscursive awareness and critical literacy (cf. Catterson \& Pearson, 2017). They also align with most essential elements of reading comprehension instruction proposed by Duke et al. (2011). Second, when prioritising reading instruction, teachers combined surface-level and deeper-level tasks, scaffolded comprehension by offering explicit strategy instruction based on student needs, and encouraged daily use of known strategies, instead of teaching new ones. The following subsections offer 


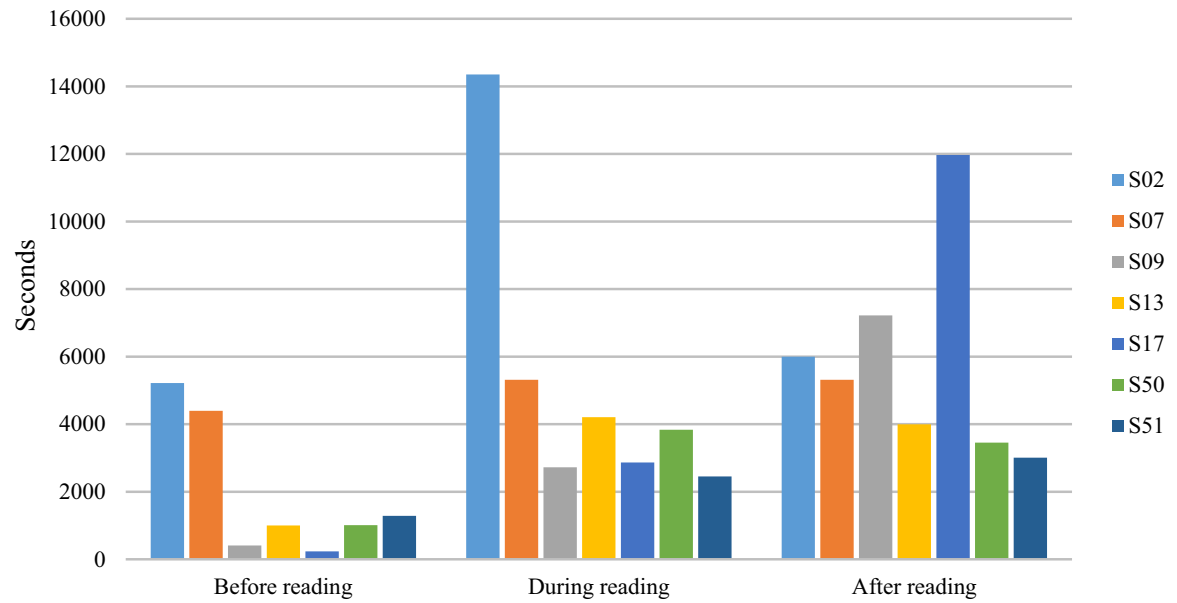

Fig. 4 Reading phases across the 47 English L2 lessons across 9th and 10th grade

descriptions of reading instruction including comprehension strategy instruction and use of such strategies, with representative excerpts.

\section{In the name of reading comprehension}

The most notable finding across the 60 English lessons is that students worked with more than half the time (56\%), providing exposure to a range of texts. Textbased reading instruction occurred in all classrooms both years, resulting in 47 recorded lessons. Figure 3 shows that a variety of authentic texts were used $(92 \%)$ alongside few non-authentic texts $(8 \%)$. Most texts $(56 \%)$ were narratives (short stories, poems, lyrics, plays, novels). The rest (44\%) covered a variety of authentic informational texts (historical documents, animations, webpages, maps, graphs) and non-authentic ones (textbook).

Differences across classrooms show that, while two classes read either narratives (School 2 [S02]) or informational texts (S07), the remaining classes read both genres. All classes except one (S02) combined print-based and digital sources. Teachers used multimedia to support printed narratives, such as video and audio adaptations of stories (S09, S50, S51) and music videos of lyrics (S13, S50). Only one classroom (S07) included multimedia supports from various online spaces, representing contrasting views.

Reading instruction in the 47 English lessons included before-reading (17\%), during-reading (38\%), and after-reading (45\%) phases, although the classrooms varied in their prioritisation of phases. Figure 4 shows that three classes spent markedly less time before reading compared to the other phases (S13, S50, S51), one class engaged more during reading (S02), while two classes invested most time after reading ( $\mathrm{S} 09, \mathrm{~S} 17)$, and only one classroom emphasised all phases almost equally (S07). Despite these differences, before-reading was commonly 
Table 3 Overview of textbased reading instruction (TBI) indicated by PLATO Scores $(\mathrm{N}=130)$

\begin{tabular}{lllll}
\hline & Score 1 & Score 2 & Score 3 & Score 4 \\
\hline $\begin{array}{l}\text { Number of 15-min } \\
\text { segments at this } \\
\text { level }\end{array}$ & 23 & 52 & 43 & 12 \\
Percentage & 18 & 40 & 33 & 9 \\
\hline
\end{tabular}

initiated when the teacher explicitly referred to the text in question, without asking them to make use of the text. The during-reading phase indicates time spent reading in the classroom, alternating between silent reading or reading aloud and trying to comprehend what the text means. The after-reading phase was initiated by the teacher explicitly asking questions about the text following students' reading.

\section{Text-based reading instruction}

Table 3 illustrates how often students were given the opportunity to engage in text-based reading instruction across each 15-minute segment of the 47 English lessons, using the TBI category described in Fig. 2. 18\% of the segments contain no opportunities to read authentic texts, scoring 1 on "use of authentic texts in instruction". The most interesting segments for further analyses are those where students read various authentic texts (segments scoring 2 [40\%], 3 [33\%], and 4 [9\%]). The following analyses provide examples of surface-level activities (score 2 ), requiring students to refer to an authentic text by focusing on recall of specific details that did not necessarily contribute to broader understanding; and deeperlevel activities (score 3), requiring students to cite evidence to construct an understanding, sometimes for a sustained period (score 4). Although the PLATO manual distinguishes between low-end and high-end scores, reading comprehension instruction should be considered in context.

\section{Before-reading phase: background knowledge}

The before-reading phase involved two distinct but interrelated close-reading practices concerning the essential element of building knowledge; teachers offering background knowledge to understand ideas in the text, and encouraging students' activation of prior knowledge. In this example of the teachers' representation of background knowledge, the teacher encourages students to link history to the Irish Declaration of Independence:

Teacher:

Student:
Why did I put up these two [Great Britain, Protestants] on the same side [of the whiteboard]?

I don't know 
Teacher:

Student:

Teacher:
What do you think? Based on history

I'm not sure. Maybe because Great Britain likes Protestants?

Yes, I mean they are in a relationship, and Ireland and the Catholics are in a relationship on the other side, so the Catholics of Ireland, they want an independent Ireland, right? And the Protestants want to be a part of Great Britain [...] So, this Declaration of Independence, which you'll see shortly, leads to violent conflict between the IRA, the Irish Republican Army, and British troops, which is not really surprising

(S07: 9th grade)

The other close-reading practice concerned the juxtaposition between predicting and activating students' knowledge. Although S50 seldom engaged in before reading, and seldom encouraged students to use existing knowledge prior to reading, this example demonstrates how students based their predictions on guessing (i.e., Student 1), while others based their predictions on prior knowledge (i.e., Student 2):

Teacher:

Student 1:

Student 2:

(S50: 9th grade)
From the title, Witch Child [by Celia Rees], I want you to think and find out without peeking in the text: Who is this text about? Where could it possibly take place? When? Is there any conflict involved? And this is just guessing, so no answer is wrong. [...]

I think, since I don't know anything, I think it's, eh, in the daytime, and like the witch child is trying to fit in with other people in the day time, or something like that

I think it's an old story. Because witches, they burned the witches before

Across lessons, teachers built background knowledge to prepare students for authentic reading opportunities.

\section{During-reading phase: authentic reading and critical literacy}

In these lessons, a range of authentic narrative and informational texts were read, with some powerful examples of teachers requiring students to interact with the texts for a sustained period of time. The following example shows how the teacher involved students as critics of "The First Day of Spring” by Howell Hurst, by requiring them to actively cite details as evidence of their deeper understanding of the text and its contextual representation of dementia:

\footnotetext{
Teacher: What happens here, now?

Student 1: $\quad$ She [Martha] finds out that Thomas was taken good care of [...] but she, like, imagines that Thomas is coming towards her

Teacher: You think it's in her imagination?

Student 1: $\quad$ Yes

Teacher: Why?

Student 1: $\quad$ Because, like, Thomas is ill, and in the beginning of the story she says that he can't get out of bed.
} 


\begin{tabular}{|c|c|}
\hline Student 2: & He can't move $[\ldots]$ \\
\hline Teacher: & $\begin{array}{l}\text { It's quite unlikely that Thomas would run towards Martha, huh? Because in the begin- } \\
\text { ning of the text, we are told that he can't, he can't move. Right? }\end{array}$ \\
\hline Student 3: & I have a theory that maybe Martha is suffering from dementia \\
\hline Teacher: & Good, why do you say that? \\
\hline Student 3: & $\begin{array}{l}\text { Since she struggles with the memory. That's the whole symptom of dementia, that you } \\
\text { can't remember }\end{array}$ \\
\hline Teacher: & Yes, absolutely, very good \\
\hline Student 3: & $\begin{array}{l}\text {... and sometimes old people get it and they remember that they had a loved one but } \\
\text { then maybe Thomas is actually dead, and she doesn't think so? }\end{array}$ \\
\hline (S02: 9th grade) & \\
\hline
\end{tabular}

Although the teacher started out with a surface-level question (What happens here now?), she continues with deeper-level questions; encouraging them to make inferences about what this means and why. Following these English classes for consecutive lessons also showed deeper understanding across texts, as in this lesson one week after the above discussion, while reading "The Lottery" by Shirley Jackson:

\begin{tabular}{ll}
\hline Teacher: & When is it taking place and what's going to happen? [...] Where is this? [...] \\
Student 4 & It's in a small village \\
Teacher: & It's in a small village, Yes, ok, we'll start there $[\ldots]$ What can we say about \\
& the atmosphere? \\
It's warm and I think it's like in "The First Day of Spring" \\
Teacher: \\
Yes, good, good way of comparison, because we have sunlight, and it's \\
warm. You think it's... uhm the weather is nice? You think it's a nice \\
place? Yes? Maybe? We don't know yet, but uhm it seems to be quite okay \\
doesn't it?
\end{tabular}

(S02: 9th grade)

Again, we see how the combination of surface-level (When is it taking place? Where is this?) and deeper-level questions (What's going to happen? What can we say about the atmosphere?) offered opportunities for the students to approach the texts critically and demonstrate deeper understanding. This way of engaging students during reading occurred in several classrooms, whether students read informational or narrative texts, paper-based or digital ones.

\section{After-reading phase: metadiscursive awareness}

A typical practice identified in this phase, was the promotion of metadiscursive awareness. The juxtaposition of surface-level and deeper-level understanding observed during reading was also identified in this phase, although with stronger emphasis on deeper comprehension (score 3-4). In some schools, students gave brief oral presentations $(6 \mathrm{~min})$ to demonstrate reading comprehension. The following example illustrates how the teacher's focus on surface-level features did not contribute to broader understanding (score 2 ): 
Teacher:

Student:

Teacher:

Student:

(S09: 9th grade)
Yeah, so, thank you. So here you showed us yet another [Chumash Indian] house. Can you take us back to the house picture, please? How was that built then?

From branches and grass

Is it grass, dried grass at the bottom?

On top I think

In other classrooms, the teachers elicited metadiscursive awareness in students by focusing on differences and similarities between narrative genres (score 3):

Teacher:

What typical features of cartoons and films can you find in the pages from the graphic novel? [...] Why can we say that the Stormbreaker novel belongs to the action genre? Find examples from the extract. [...] What was his idea, Anthony Horowitz, when he was writing the Stormbreaker?

Student: $\quad$ He was inspired by Lord of the Rings, wanted to make the same story in a different universe.

Teacher: $\quad$ Real world Lord of the Rings. Exciting. You were last asked to find examples of why the Stormbreaker belongs to the action genre.

Student: $\quad$ Well, it's quite like James Bond

Teacher: $\quad$ And James Bond is an action film, isn't it?

Student It's pretty similar

(S17: 9th grade)

Students developed understanding of the action genre by comparing and contrasting Stormbreaker by Anthony Horowitz, Anthony Johnson, Kanako, and Yuzuru Takasaki across platforms (novel, graphic novel, audio), and compared it to action films. Similarly, in another classroom, the teacher elicited students' metadiscursive awareness of literary concepts after reading “The Sniper” by Liam O'Flaherty:

Teacher:
Student 1:
Teacher: $\quad \begin{aligned} & \text { The sniper, that is a kind of shooter? } \\ & \text { so all the weapons will underline what theme? What could a theme be if you have a } \\ & \text { lot of weapons and things like that? }\end{aligned}$

Student 2: War, assassination

Teacher: [...] It obviously has a lot to do with assassination, yes...because his title is a "sniper"

Student 3: Well, I would say, kind of the, the theme is conflict. Because, uh...it gets kind of obvious that this person is tired; he doesn't really want to kill someone. There's, like, this point in the story where he kind of gets a real adrenaline rush. Kills the person, he's like, yeah! And then gets really sad because he didn't actually want to kill someone. [...] Even though he wants to shoot this person so he can survive, he doesn't really want to shoot this person. It's really a lot of conflict

Teacher: Ok. So if we expand...this is good. That's one of the conflicts. And then if we expand even wider... what might the author try to say the conflict is?

Student 1: $\quad$ Getting out of a bad position [...]

Teacher: $\quad$ Bad position...this is...might be true 
Table 4 Overview of strategy use and instruction (SUI) indicated by PLATO Scores $(\mathrm{N}=130)$

\begin{tabular}{lllll}
\hline & Score 1 & Score 2 & Score 3 & Score 4 \\
\hline $\begin{array}{l}\text { Number of 15-min } \\
\text { segments at this } \\
\text { level }\end{array}$ & 63 & 61 & 6 & 0 \\
Percentage & 48 & 47 & 5 & 0 \\
\hline
\end{tabular}

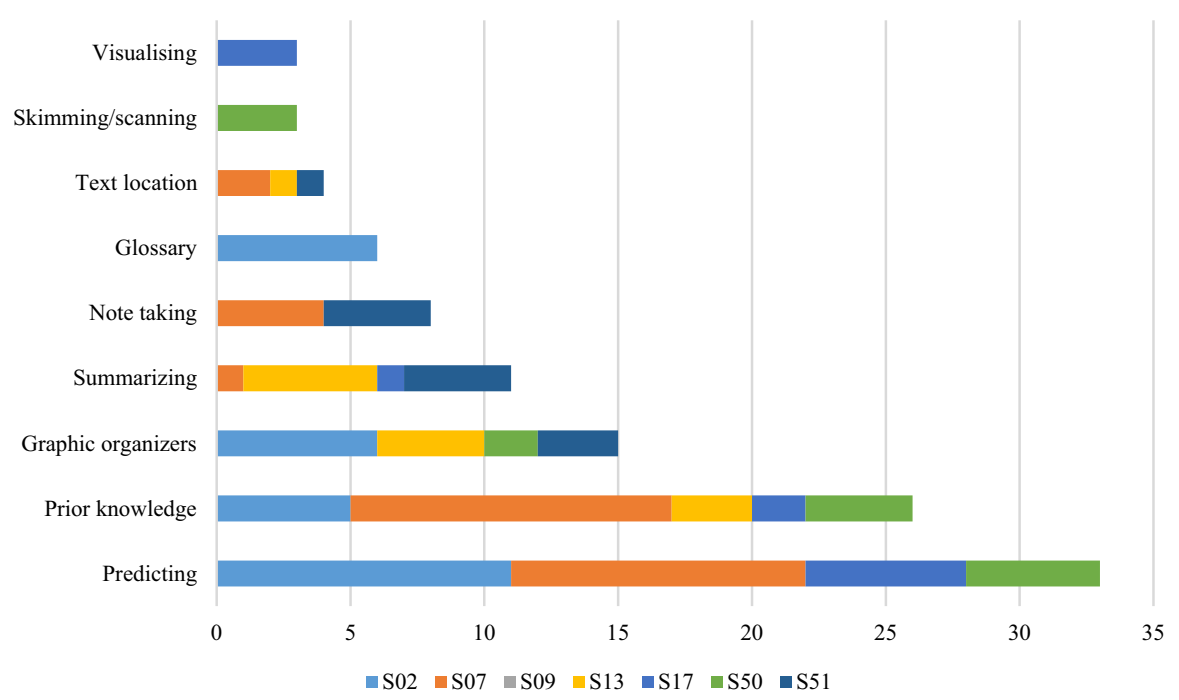

Fig. 5 Frequencies of reading comprehension strategies identified across 27 English lessons (9th-10th grade). Note: Each strategy is counted once for each 15-min segment in which it occurs

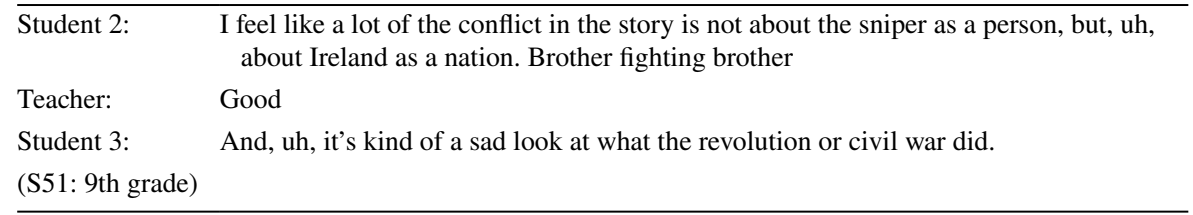

The reading situations in these English lessons showed how teachers engaged students in authentic reading to develop background knowledge, critical literacy, and metadiscursive awareness. However, throughout their instruction, scaffolding practices in terms of reading strategy use varied extensively. This key feature of reading comprehension is elaborated below.

\section{Scaffolded reading strategy use and instruction}

Table 4 illustrates how often students were offered scaffolded reading strategy use and instruction across each 15-minute segment of the 47 English lessons, using the SUI category described in Fig. 2. Critically, $48 \%$ of the segments contain no strategy 
use or instruction, scoring 1, and in addition no segments contained explicit and detailed strategy instruction (score 4). The relevant segments for further analyses are those demonstrating students' daily use of strategies, scoring 2 (47\%), as well as explicitly instructed and guided, scoring $3(5 \%)$.

These scaffolded reading strategy practices were identified in 27 English lessons. A total of nine strategies were observed, except in S09, where the teaching or use of strategies for comprehending was not observed either school year (Fig. 5). Four strategies were used in most classrooms (predicting, prior knowledge, graphic organisers, and summarising), while fewer classrooms used the remaining five (notetaking, glossary, text location, skimming/scanning, and visualising).

While some strategies were instructed explicitly (score 3), all were part of daily use in these classrooms (score 2), prompted by teachers and used by students. The following subsections describe these multiple versions of strategic actions.

\section{Explicit strategy instruction}

Although few lessons offered explicit strategy instruction, they occurred across four classrooms (S07, S17, S50, S51), and illustrate that, for students to develop successful strategic reading, they need scaffolding. Teachers offered modelling and guided practice when students showed less than independent control related to close reading practices, to develop their comprehension.

\section{Strategy modelling}

In contrast to the notion of explicit modelling of new strategies, the modelling sequences in these classrooms demonstrated how to combine multiple known strategies, based on student needs. Examples include activating prior knowledge (before reading), accessing authentic sources to initiate critical literacy (during reading), and developing metadiscursive awareness (after reading). In one classroom, the teacher noted students' insufficient activation of prior knowledge before reading a text about the $1960 \mathrm{~s}$, despite the practice of seldom prioritising before reading in this classroom. Here, however, he responded by immediately modelling how to graphically organise their knowledge in writing (Fig. 6):

Teacher:

You have talked about what you already know, and we're going to organise that information in a mind map. [...] So we're talking about the sixties [writes "sixties" in the centre]. Let's start with "culture" [writes]. Do you know anything about music, for instance? Because in our last music lesson, we talked about the music, and we mentioned some artists.

Student 1: $\quad$ The Beatles?

Teacher: $\quad$ The Beatles, very good! The Beatles were great [writes] Ta-da! Other names? It's been a while.

Student $2 \quad$ Elvis

Teacher: $\quad$ Elvis, yes, Elvis [writes]. And how would you describe his music, his style? What did we call this kind of music? 


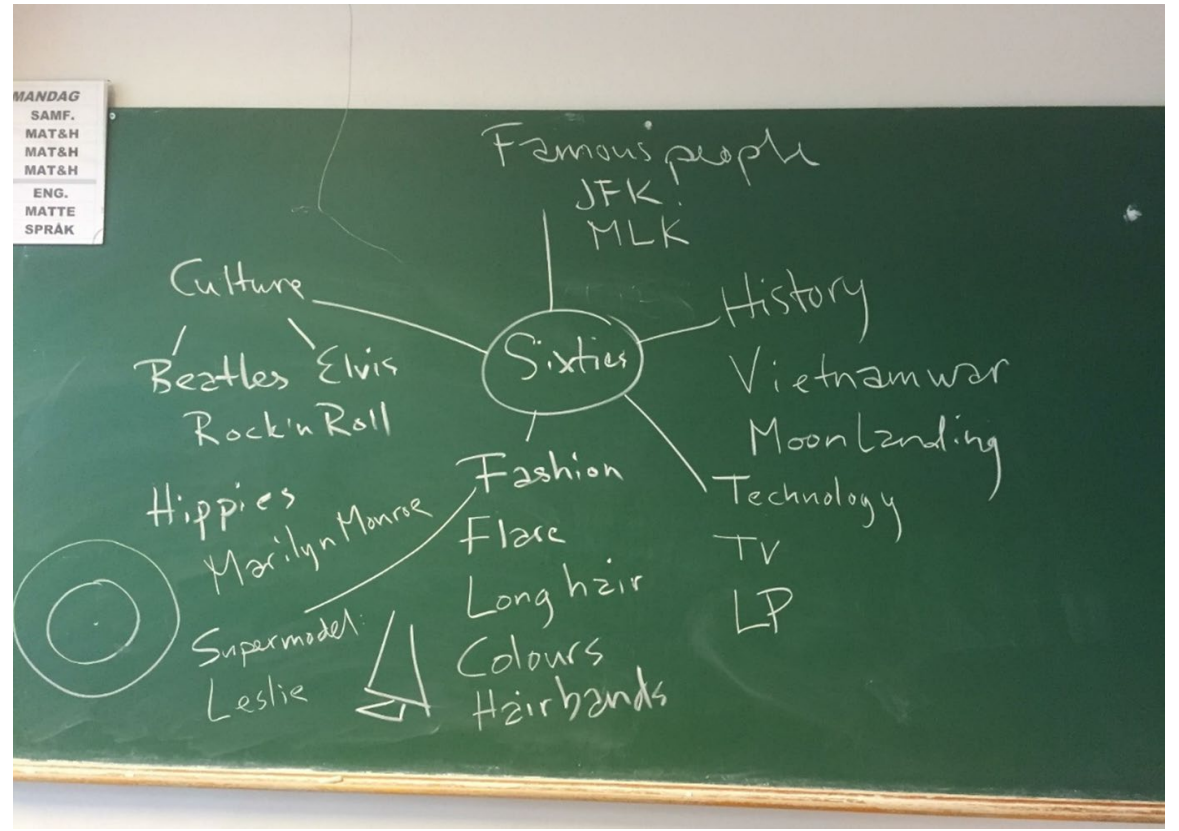

Fig. 6 Explicit strategy instruction. The teacher models how to use a graphic organiser (mind map) to activate prior knowledge (S50)

\begin{tabular}{|c|c|}
\hline Student 3: & $\mathrm{RnB}$, or? \\
\hline Student 4: & Rock'n roll. \\
\hline Teacher: & $\begin{array}{l}\text { Rock'n roll, yes [writes]. So rock'n roll was important in the sixties. Later in the six- } \\
\text { ties we are going to read about a movement. They let their hair grow. Does anyone } \\
\text { know what I'm thinking about? People who let their hair grow. }\end{array}$ \\
\hline Student 5: & Hippies? \\
\hline Teacher: & $\begin{array}{l}\text { The hippies! [writes] Very good, so you've heard about the hippies. [...] Other things, } \\
\text { other important things that happened in the Sixties? Yes? }\end{array}$ \\
\hline Student 6: & John F. Kennedy was shot. \\
\hline Teacher: & $\begin{array}{l}\text { Yes, very good. Let's put him under famous people. [writes] Famous people. I'll } \\
\text { simply write 'JFK' }\end{array}$ \\
\hline (S50: 9th grade) & \\
\hline
\end{tabular}

The teacher kept modelling how students might graphically map their prior knowledge in this way, until he closed the sequence, commenting that they knew more than initially realised: "Very well, ok, then you know quite a lot from before about the sixties". Other examples of modelling sequences concerned how to access authentic Internet texts, where the teachers demonstrated how to use text location to find information about UNESCO world heritage sites (S13), with subsequent evidence of students' individual use, or to identify the most recent US presidential election polls: 
Teacher:

We should actually find a poll of today, shouldn't we? [...] So, we'll Google, and we'll go to "US election". The English word for meningsmåling is "poll". Polls 2016. Today is the 4th of November [clicks], Telegraph.co.uk. We trust The Telegraph. See? Any polls here? Right.

(S07: 10th grade)

Using US election and polls 2016 as search terms to generate effective texts, the teacher showed how to access the Internet information space of possible texts to read. Applying his prior knowledge of Web addresses, he asserted that the online version of the UK newspaper The Telegraph is a reliable source to learn about the latest US election polls. Once accessed, the website presented a graph (Fig. 6). The excerpt shows the flexible nature of this strategy for students' future Internet readings, suggesting how they as strategic readers can conduct their own searches and make inferences about the author, quality, content, value, and potential ways of reading such polls.

\section{Guided strategy practice}

The second set of explicit strategy instruction concerns guided practice. While the teacher takes primary responsibility when modelling a strategy, guided practice more heavily involves students. In contrast to the modelling sequences, teachers offered guided practice in response to students' misconception of how to use a strategy. This was most visible in a situation, when the teacher acknowledged her students' poor note-taking skills as they copied from her PowerPoint presentation. This is a real testimonial in terms of the teacher immediately responding to student needs, guiding them in how to use note-taking strategically, and acknowledging the evidence of their strategic note-taking. It became clear that she had previously explained to them how to take notes by writing key words that capture the main idea of a paragraph:

Teacher:

Student 2:

Teacher:

Student 1:

Teacher:

Student 1:

Teacher:

Student 1:

Teacher:

Student 1:

Teacher:
No! Don't write everything, sweetheart. You're taking notes. Don't write everything

Write the things you need to know

Right, keywords. Right. This one would be important [pointing to the presentation], and then you could just write the, ah, "students should not need to worry". But you certainly don't need to read... write all this. You could write "clear", "statement", "clear statement". What else could you write?

Uh...

Like a keyword

Uh. You could write the example

Yeah? The example, is that a keyword?

No but it's, uh...

It's very, it's essential, yeah, I can see that. What about from here? [points to presentation]

Uh, well, "readers" or "intense"

$\mathrm{Ok}$, on the way 


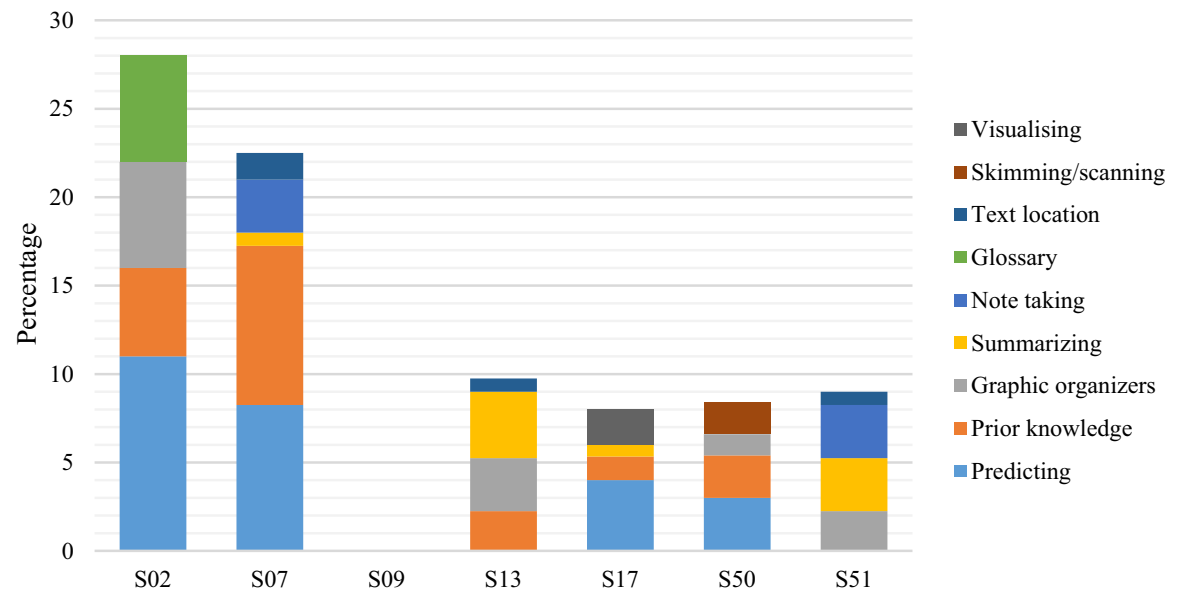

Fig. 7 Reading comprehension strategy repertoire in each of the seven classrooms (9th-10th grade). Note: Each strategy is counted once for each 15-min segment in which it occurs and then adjusted to a standardised number of video-recorded lessons in the classroom

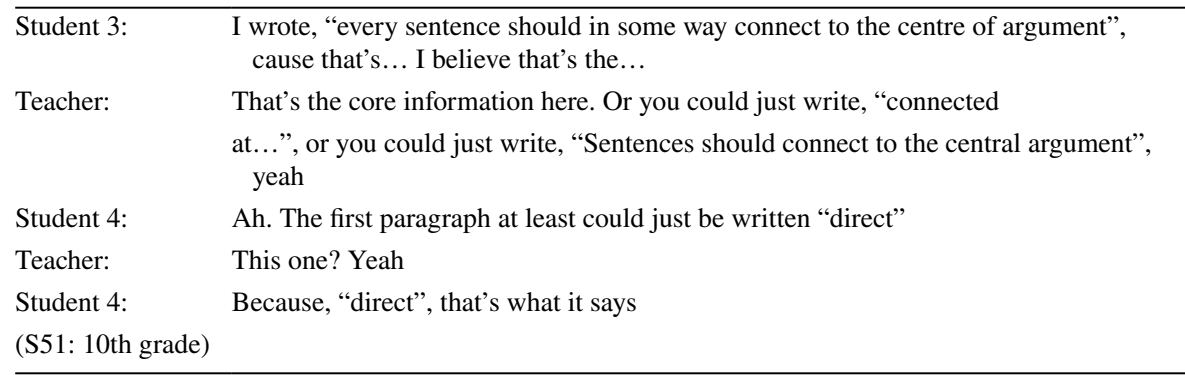

Across classrooms, teachers responded to student needs by providing modelling and guided practice to help them independently use strategies before reading, during reading and after reading.

\section{Daily use of strategies}

In addition to explicit strategy instruction, the video observations showed evidence of students' daily use of strategies. Figure 7 illustrates that based on the frequency of strategy use, these classrooms can be divided into two groups; high-frequency (S02, S07), and low-frequency strategy instruction classes (S13, S17, S50, S51). In addition, there was one class with no observed strategy instruction or use (S09), where the focus was on the reading activity ("just" reading) rather than the reading process (how to read strategically) (cf. Brevik, 2014). Despite the difference in frequency, each of the remaining six classes used a repertoire of four-five strategies, identified across two school years, framing these classes' daily use of strategies. 


\section{High-frequency strategy instruction}

The high-frequency strategy instruction was characterised by multiple strategy use to understand either narrative texts (S02) or informational texts (S07), as part of their comprehension instruction and development of critical literacy. These strategy practices were complex, as more than one strategy were typically prompted or used not only across lessons, but also within the same lesson. By regularly prompting the same strategies, teachers arranged the conditions to allow students to progress over time, and such scaffolding seemed to reinforce students' independence. Both classes frequently combined prediction and activation of prior knowledge, before and during reading. Teachers also prompted two or three specific strategies, depending on students' needs.

S02 demonstrated high-frequency strategy instruction to construct meaning from authentic short stories, as in "The First Day of Spring" by Howell Hurst, where students predicted that Martha was suffering from dementia and used their prior knowledge to compare stories. In S07, predicting and activation of prior knowledge were intertwined before and during reading, both school years, to understand informational texts about Irish history (9th grade) and the US presidential election (10th grade). The following excerpt demonstrates how these strategies were also used independently by students; predicting (i.e., Students 1-2) and activating prior knowledge (i.e., Student 2):

Student 1:

Teacher:

Student 2:

(S07: 9th grade)
Let me guess, America comes in and saves the day with another war? Interesting thoughts, no actually, the Americans are not too involved in this. Bill Clinton, the President of the USA at this time, he's somewhat involved; he does talk to people. But, it is actually the British and the Irish that come up with a solution themselves with some American help, but I like how you predicted that the USA would be involved $[\ldots]$

The only thing the Irish have fought for is independence, so I don't think the Irish would accept it. I think there will be a lot of riots and uprisings.

Scaffolding demands individualisation, which was observed in these classes, as teachers varied their scaffolding between students during and after reading. In $\mathrm{S} 02$, the teacher prompted the use of graphic organizer (word wall) or glossary to students who struggled with unknown words in the texts; encouraging them to use these strategies to solve unclear story parts, with evidence of individual students' use. In S07, the teacher prompted summarizing, text location, and note-taking based on students' needs. For example, during reading of the Irish Declaration of Independence, he suggested to individual students they could choose note-taking strategies that worked for them (i.e., underlining, keywords, or drawing): 


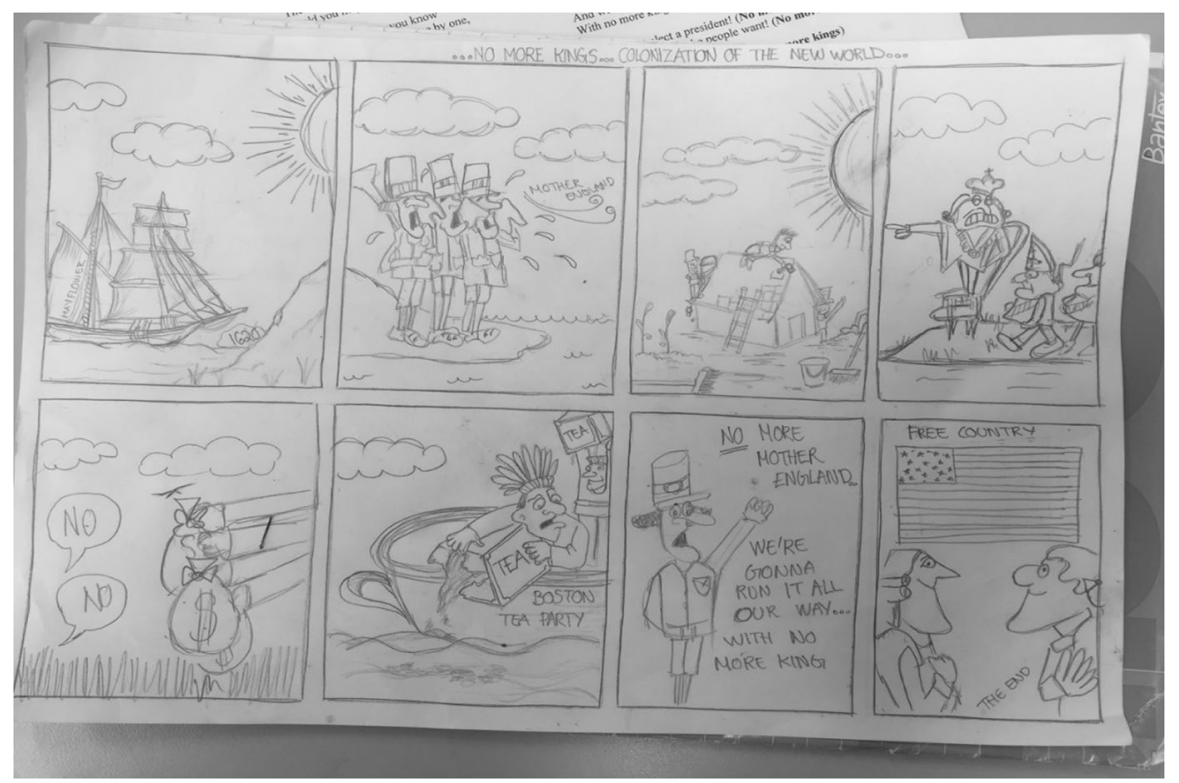

Fig. 8 Summarising using a graphic organiser (storyboard) to show reading comprehension from the lyrics and music video "No More Kings" about the American Revolution (S13)

Teacher:

Teacher:

Student 2:

Teacher: [in plenary] Even though you don't understand every single word, I know it's difficult, so do your best, try to get an impression of how the Irish feel, what they feel about England, and so on. [...] Just write some keywords to the questions, or underline them in the text, if you want to.

[to Student 1] At least you are smart enough to underline. $\mathrm{Oh}$, is it ok if we underline?

[to Student 2] Of course, it's your document. Feel free to take notes in the document, underline important words, make some drawings if that helps you remember [...] and if the document doesn't make any sense, I can reveal that the Irish people didn't like the British people too much. So try to find some evidence for that, for that view.

(S07: 9th grade)

\section{Low-frequency strategy instruction}

The low-frequency strategy instruction classes used the strategies infrequently for narrative and informational text comprehension. The daily use of strategies in these classes was predominantly about using a strategy as a tool in specific situations, by demonstrating or fixing comprehension, or in response to their 


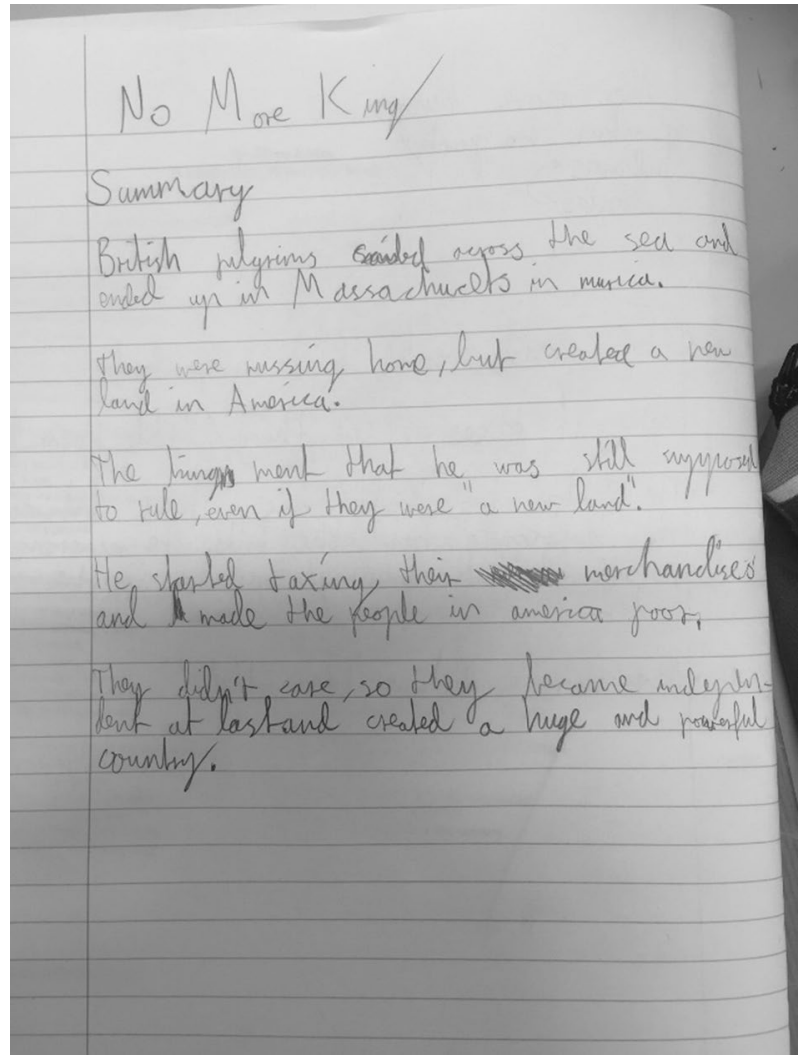

Fig. 9 Summarisation as written text to show reading comprehension from the lyrics and music video "No More Kings" about the American Revolution (S13)

inefficient strategy use, as in the previously mentioned example where the teacher from S50 modelled how to activate and organise prior knowledge in a mind map, and when the teacher at S51 guided students in strategic note-taking. An example of contextualised single strategy use is from S13, where students were asked to show comprehension of a digital YouTube text about the American Revolution. While some students used summarizing in the form of graphic organiser (storyboard; Fig. 8), others used note-taking to demonstrate comprehension (Fig. 9).

Figures 8 and 9 show how students in the low-frequency classrooms chose different strategies for the same purpose, which demonstrated how the teacher released responsibility for strategy use to the students. These scaffolding practices demonstrate teachers' strategy prompting and students' independent strategy use. They illustrate how strategy use across lessons and school years support reading comprehension development of authentic texts. Following these seven classrooms for two school years indicated that teachers reduced the amount of scaffolding as students developed greater independent control of strategy use. They not only 
prioritised explicit strategy instruction, but also provided opportunities for daily use of strategies.

\section{Discussion}

Research since the 1980s has found that most reading classrooms neglect comprehension strategy instruction, which is worrying, since training of certain comprehension strategies has proven effective for student reading comprehension, in L1 and L2 (Brown, 2017; Grabe, 2009; Kamil et al., 2011; Pressley, 2008). The major concern is not whether or how to offer explicit strategy instruction, but finding a way to sustain strategies instruction beyond initial explaining, modelling and scaffolding; making strategy use part of daily life in the classroom (Aukerman et al., 2015; Brown, 2017; Grabe, 2009; Koda, 2007; Pearson, \& Cervetti, 2017), whether printed, digital or online texts are read (cf. Cho, \& Afflerbach, 2017).

This study has identified some powerful practices of doing so, based on student needs and differences, indicating in line with Duke et al. (2011) that the essential element of teaching strategies for comprehending indeed occurred in most classrooms. For example, the demand on teachers to encourage strategic reading was evident in the situations where the students either did not consciously choose to activate the prior knowledge they clearly had (e.g., about the 1960s in S50) or where they used strategies inefficiently (e.g., note-taking in S51). In these situations, observation and evaluation of students' needs were of utmost importance (Duke et al., 2011), and the teachers' immediate modelling and prompting of relevant strategies support Pearson and Cervetti's (2017) argument that teachers must find ways of making strategies part of 'daily life' in the classroom.

The most transparent insight concerns the varying of scaffolding within and across lessons and between students, and the fading of scaffolding over time to enable students' independent use of strategies (McVee et al., 2018). This observation aligns with Koda (2005), who underscores that accomplished L2 readers engage in strategic reading to "continuously adjust their reading behaviors to accommodate text difficulty, task demands, and other contextualized variables" (p. 204). The study shows how reading comprehension instruction appears to serve two main purposes in the English L2 classrooms; high-frequency and low-frequency strategy instruction. In the low-frequency strategy instruction classrooms, single strategies were used by individual students demonstrating or fixing comprehension of specific texts. Here, teachers modelled and guided strategy use primarily when students showed a lack of complete control over specific strategies, rather than text content.

A key finding of this study is that in the high-frequency classrooms, the observed practices were often framed within a close reading discourse (Catterson, \& Pearson, 2017) and in line with the essential elements proposed by Duke et al. (2011). Here, teachers emphasised how and why to provide exposure to a volume and range of authentic texts, and promoted the thoughtful interrogation of text across phases, several of which seemed motivating to the students on the basis of their responses; ranging from the building and use of disciplinary background knowledge to the development of metadiscursive awareness and critical literacy. Such essential 
elements of reading comprehension emphasise the critical position of the reader and the context in constructing meaning from text (RAND, 2002) and engaging students in discussion (Duke et al., 2011). In these classrooms, strategies were taught for comprehending texts, the strategy instruction was explicit and scaffolded, and students commonly practiced multiple strategy use with and without their teacher prompting them to do so (Afflerbach et al., 2017; Duke et al., 2011; Pressley, \& Afflerbach, 1995). These scaffolding practices show how the strategy use within a single lesson sometimes demonstrates to students that they are more self-reliant at the end of the lesson than at the beginning. Scaffolding independent strategy use can be crucial to differentiate the instruction and for developing constructively responsive readers (Cho, \& Afflerbach; 2017; Duke et al., 2011).

Key here is the consistent use of a small repertoire of strategies within and across lessons and school years, in line with RAND's (2002) view on the role of teachers: "They should teach comprehension strategies that foster deep understanding of relevant content matter and give students ample opportunities to employ them" (p. 101). Although high-frequency strategy use is not by itself the solution to reading comprehension, offering ample opportunities to use a variety of strategies is nevertheless key for students to gain experience with strategic reading, which in turn is necessary to enabling them to make conscious - and independent - choices of which strategies to use in which situations. "It is a 'Goldilocks' principle at work-not too much, not too little, but just the right amount" (McVee et al., 2018, p. 10, original emphasis), however, the right amount is not easily determined (Wilkinson, \& Son, 2011).

The one repeated strategy use identified across high- and low-frequency classrooms, was the combination of predicting and activation of prior knowledge, in line with strategies found to be effective or worth teaching in prior studies (Cho, \& Afflerbach, 2017; Duke et al., 2011; Brevik, 2014, 2017; Brevik, \& Hellekjær, 2018; Grabe, 2009; NICHD, 2000). These strategies seemed to be at the core of comprehension instruction, and also commonly combined with other strategies, across lessons and school years, indicating one way of making strategy use part of daily life in the classrooms. The same strategies seemed to be used across classrooms and reading phases for both print, digital and online material, with the exception of text location, which was only observed during reading of online texts. These observations align with Cho and Afflerbach's (2017) argument on the need for strategies that support the comprehension of Internet texts. In stark contrast to many of the studies reviewed above, this study found that in the name of reading comprehension, teachers do prioritise reading comprehension instruction, prompting strategy use as an integrated and differentiated part of this process (Duke et al., 2011).

Through systematic investigation of 60 English L2 lessons in seven classrooms across two school years, this study supports research arguing that explicit strategy instruction is not the aim, but sometimes a necessary practice to develop students into strategic readers (Brown, 2017; Pearson, \& Cervetti, 2017) who consciously and independently use strategies to overcome comprehension problems (Afflerbach et al., 2017). There is the possibility that teachers in this study might have known that their students had encountered strategies before, especially since students move from primary to secondary school in 8th grade, whereas we filmed 9th and 10th grade. 8th grade might then be the preferred year of teaching new strategies to 
students, specifically, since the teachers would not know which strategies they had learnt in primary school. However, precisely for this reason, it would be expected that the teachers prompted the use of strategies in 9th and 10th grade instead of teaching new ones, which also makes it interesting to see that the teachers in some of these classrooms react to the fact that the students do not use a known strategy (e.g., the lack of activation of prior knowledge in S50) or use it incorrectly (e.g., the note-taking in S51), and even models what might be a known strategy to them (e.g., text location in S07).

Thus, explicitly learning about a reading comprehension strategy will not easily propel the student forward, but using it as part of their daily reading practices, to expand learning capacity might promote and repair reading comprehension (Brevik, $2015,2017)$. As little evidence exists of reading comprehension strategy instruction in reading classrooms in general and specifically in English L2, the present study contributes with important information on aspects of reading comprehension and strategy instruction. While close reading (Catterson, \& Pearson, 2017) does not guarantee independent or daily use of reading strategies, this study identified a clear relationship between what goes on in the name of reading comprehension and the scaffolding of reading comprehension strategies. Given this finding, it is tempting to suggest that teachers should make strategy use part of daily life in English L2 classrooms, and that this is more critical than explicit strategy instruction.

The main contribution of this study lies in the systematic and detailed exploration of reading comprehension instruction across 60 English L2 lessons. This study raises new questions of why teachers choose to teach strategies explicitly compared to the prompting of students' daily use of strategies, and whether students' daily use of strategies in the L2 classroom develops their strategic reading over time. Future research should thus give priority to observational designs combined with student and teacher perspectives, to capture diverse voices (cf. Greene, 2007), e.g., by selecting video segments from classroom observations to use for stimulated recall interviews. Such questions furthermore indicate a need for longitudinal research to follow up on the effects of making strategy use part of daily life for students in the English L2 classroom to enhance reading comprehension.

Acknowledgements The research described in this article is part of the project Linking Instruction and Student Experiences led by Kirsti Klette and coordinated by Lisbeth M Brevik, University of Oslo.

Open Access This article is distributed under the terms of the Creative Commons Attribution 4.0 International License (http://creativecommons.org/licenses/by/4.0/), which permits unrestricted use, distribution, and reproduction in any medium, provided you give appropriate credit to the original author(s) and the source, provide a link to the Creative Commons license, and indicate if changes were made.

\section{References}

Aasen, P., Møller, J., Rye, E., Ottesen, E., Prøitz, T. S., \& Hertzberg, F. (2012). Kunnskapsløftet som

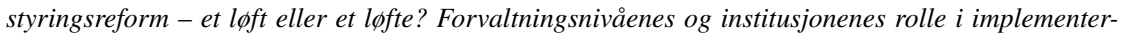
ingen av reformen. [The Knowledge Promotion as a Steering Reform-A Lift or a Promise?] NIFU Report, 20. Oslo: NIFU/Institutt for lærerutdanning og skoleforskning, University of Oslo. 
Afflerbach, P., Pearson, P. D., \& Paris, P. (2017). Skills and strategies: Their differences, their relationships, and why they matter. In K. Mokhtari (Ed.), Improving reading comprehension through metacognitive reading strategies instruction (pp. 33-50). Lanham, MD: Rowman and Littlefield.

Anmarkrud, Ø. (2009). Undervisning i lesestrategier ogutvikling av lesemotivasjon på ungdomstrinnet: En klasseromsstudie av fire norsklareres arbeid med forklarende tekst [Reading strategies instruction and development of reading motivation in secondary classrooms: A classroom study of four Norwegian teachers' work with explanatory text] (Unpublished doctoral dissertation). Norway: University of Oslo.

Anmarkrud, Ø., \& Bråten, I. (2012). Naturally-occurring comprehension strategies instruction in 9thgrade language arts classrooms. Scandinavian Journal of Educational Research, 56(6), 591-623. https://doi.org/10.1080/00313831.2011.621134.

August, D., \& Shanahan, T. (2006). Developing literacy in second-language learners: Report of the national literacy panel on language minority children and youth. Mahwah, NJ: Lawrence Erlbaum Associates.

Aukerman, M., Brown, R., Mokthari, K., Valencia, S., \& Palincsar, A. (2015). Examining the relative contributions of content knowledge and strategic processing to reading comprehension. Literacy Research: Theory, Method, and Practice, 64, 73-91.

Boardman, A. G., Boelé, A. L., \& Klingner, J. K. (2017). Strategy instruction shifts teacher and student interactions during text-based discussions. Reading Research Quarterly, 53, 175-195.

Bråten, I., \& Anmarkrud, Ø. (2013). Does naturally occurring comprehension strategies instruction make a difference when students read expository text? Journal of Research in Reading, 36(1), 42-57. https://doi.org/10.1111/j.1467-9817.2011.01489.x.

Brevik, L. M. (2014). Making implicit practice explicit: How do upper secondary teachers describe their reading comprehension strategies instruction? International Journal of Educational Research, 67, 52-66. https://doi.org/10.1016/j.ijer.2014.05.002.

Brevik, L. M. (2015). How teachers teach and readers read. Developing reading comprehension in English in Norwegian upper secondary school (Unpublished doctoral dissertation). Oslo, Norway: University of Oslo.

Brevik, L. M. (2017). Strategies and shoes: Can we ever have enough? Teaching and using reading comprehension strategies in general and vocational programmes. Scandinavian Journal of Educational Research, 61(1), 76-94. https://doi.org/10.1080/00313831.2015.1075310.

Brevik, L. M., \& Hellekjær, G. O. (2018). The outliers: Upper secondary school students who read better in the L2 than in L1. International Journal of Educational Research, 89, 80-91. https://doi. org/10.1016/j.ijer.2017.10.001.

Brown, R. (2017). Comprehension strategies instruction for learners of English: Where we have been, where we are now, where we still might go. In S. E. Israeli (Ed.), Handbook of research on reading comprehension (pp. 543-567). New York, NY: The Guilford Press.

Catterson, A. K., \& Pearson, P. D. (2017). A close reading of close reading: What does the research tell us about how to promote the thoughtful interrogation of text? In K. A. Hinchman \& D. A. Appleman (Eds.), Adolescent literacies: A handbook of practice-based research (pp. 457-476). New York, NY: Guilford.

Cho, B., \& Afflerbach, P. (2017). An evolving perspective of constructively responsive reading comprehension strategies in multilayered digital text environments. In S. E. Israeli (Ed.), Handbook of research on reading comprehension (pp. 109-134). New York, NY: The Guilford Press.

Cohen, A. (2011). L2 learner strategies. In E. Hinkel (Ed.), Handbook of research in second language teaching and learning (Vol. II, pp. 681-698). Abingdon: Routledge.

Cohen, J., \& Grossman, P. (2016). Respecting complexity in measures of teaching: Keeping students and schools in focus. Teacher and Teacher Education, 55, 308-317.

Cohen, J., Schuldt, L. C., Brown, L., \& Grossman, P. (2016). Leveraging observation tools for instructional improvement: Exploring variability in uptake of ambitious instructional practices. Teachers College Record, 118(110), 1-37.

Duke, N. K., Pearson, P. D., Strachan, S. L., \& Billman, A. K. (2011). Essential elements of fostering and teaching reading comprehension. In S. J. Samuels \& A. E. Farstrup (Eds.), What research has to say about reading instruction (pp. 51-93). Newark, DE: International Reading Association.

Grabe, W. (2009). Reading in a second language: Moving from theory to practice. Cambridge: Cambridge University Press.

Greene, J. C. (2007). Mixed methods in social inquiry (1st ed.). New York, NY: Wiley. 
Grossman, P. (2010). The Plato protocol for classroom observations. Seattle, WA: Bill \& Melinda Gates Foundation.

Grossman, P., Loeb, S., Cohen, J., \& Wyckoff, J. (2013). Measure for measure: The relationship between measures of instructional practice in middle school English language arts and teachers' value-added scores. American Journal of Education, 119, 445-470.

Hassan, X., Macaro, E., Mason, D., Nye, G., Smith, P., \& Vanderplank, R. (2005). Strategy training in language learning-A systematic review of available research. London: EPPI-Centre, Social Science Research Unit, Institute of Education, University of London.

Hertzberg, F., \& Roe, A. (2016). Writing in the content areas: A Norwegian case study. Reading and Writing: An Interdisciplinary Journal, 29, 555-576.

Hilden, K. R., \& Pressley, M. (2007). Selfregulation through transactional strategies instruction. Reading \& Writing Quarterly, 23(1), 51-75.

Israeli, S. E. (2017). Preface. In S. E. Israeli (Ed.), Handbook of research on reading comprehension (pp. xii-xviii). New York, NY: The Guilford Press.

Kamil, M. L., Afflerbach, P., Pearson, P. D., \& Moje, E. B. (2011). Preface Reading research in a changing era: An introduction to the Handbook of Reading Research. In M. L. Kamil, P. Afflerbach, P. D. Pearson, \& E. B. Moje (Eds.), Handbook of reading research (Vol. IV, pp. xiii-xxvi). New York, NY: Routledge.

Klette, K., Blikstad-Balas, M., \& Roe, A. (2017). Linking instruction and student achievement. A research design for a new generation of classroom studies. Acta Didactica, 11(3), 1-19.

Klingner, J. K., \& Vaughn, S. (1996). Reciprocal teaching of reading comprehension strategies for students with learning disabilities who use English as a second language. Elementary School Journal, 96, 275-293.

Koda, K. (2005). Insights into second language reading. New York: Cambridge University Press.

Koda, K. (2007). Reading and linguistic learning: crosslinguistic constraints on second language reading development. Language Learning, 57(1), 1-44.

Magnusson, C. G., Roe, A., \& Blikstad-Balas, M. (2018). To what extent and how are reading comprehension strategies part of language arts instruction? A study of lower secondary classrooms. Reading Research Quarterly, 54(2), 187-212. https://doi.org/10.1002/rrq.231.

McNeil, L. (2011). Investigating the contributions of background knowledge and reading comprehension strategies to L2 reading comprehension: an exploratory study. Reading and Writing: An Interdisciplinary Journal, 24, 881-902.

McVee, M. B., Shanahan, L. E., Hayden, H. E., Boyd, F. B., Pearson, P. D., \& Reichenberg, J. S. (2018). Video pedagogy in action: Critical reflective inquiry using the gradual release of responsibility model (pp. 1-22). New York, NY: Routledge.

Meyer, B. J., Wijekumar, K., \& Lei, P. (2018). Comparative signaling generated for expository texts by 4th-8th graders: variations by text structure, strategy instruction, comprehension skill, and signal word. Reading and Writing: An Interdisciplinary Journal, 31(9), 1937-1968.

National Committee for Research Ethics in the Social Sciences and the Humanities. (2006). Guidelines for Research Ethics in the Social Sciences, Law and the Humanities.

National Institute of Child Health and Human Development. (2000). Report of the National Reading Panel: Teaching children to read: An evidence-based assessment of the scientific literature on reading and its implications for reading instruction: Reports of the Subgroups (NIH Publication No. 00-4754). Washington, DC: U.S. Government Printing Office.

Norwegian Directorate for Education and Training. (2012). Framework for basic skills. Oslo, Norway: Author.

Palincsar, A. S., \& Brown, A. L. (1984). Reciprocal teaching of comprehension-fostering and comprehension monitoring activities. Cognition and Instruction, 1, 117-175.

Paris, S. G., Wasik, B. A., \& Turner, J. C. (1991). The development of strategic readers. In R. Barr, M. L. Kamil, P. B. Mosenthal, \& P. D. Pearson (Eds.), Handbook of reading research (Vol. II, pp. 609-640). New York, NY: Routledge.

Pearson, P. D., \& Cervetti, G. N. (2017). The roots of reading comprehension instruction. In S. E. Israeli (Ed.), Handbook of research on reading comprehension (pp. 12-56). New York, NY: The Guilford Press.

Pearson, P. D., \& Gallagher, M. C. (1983). The instruction of reading comprehension. Contemporary Educational Psychology, 8, 317-344.

Plonsky, L. (2011). The effectiveness of second language strategy instruction: A meta-analysis. Language Learning, 61, 993-1038. 
Pressley, M. (2008). Epilogue. What the future of reading research could be. In C. C. Block \& S. R. Parris (Eds.), Comprehension instruction. Research-based best practices (pp. 391-413). New York, NY: The Guilford Press.

Pressley, M., \& Afflerbach, P. (1995). Verbal protocols of reading: The nature of constructively responsive reading. Hillsdale, $\mathrm{NJ}$ : Lawrence Erlbaum Associates.

RAND Reading Study Group. (2002). Reading for understanding. Toward an R\&D program in reading comprehension. RAND Reading Study Group. Santa Monica, CA: Rand Education.

Taylor, A. M., Stevens, J., \& Asher, J. W. (2006). The effects of explicit reading strategy training on L2 reading comprehension: A meta-analysis. In J. M. Norris \& L. Ortega (Eds.), Synthesizing research on language learning and teaching (pp. 213-244). Philadelphia, PA: Benjamins.

UNESCO. (2004). The plurality of literacy and its implications for policies and programs: Position paper (Vol. 13). Paris, France: United National Educational, Scientific and Cultural Organization.

Wilkinson, I. A. G., \& Son, E. H. (2011). A dialogic turn in research on learning and teaching to comprehend. In M. L. Kamil, P. Afflerbach, P. D. Pearson, \& E. B. Moje (Eds.), Handbook of reading research (pp. xiii-xxvi). London: Routledge.

World Bank. (2013). Inclusion Matters: The Foundation for Shared Prosperity. New Frontiers of Social Policy. Washington, DC: World Bank.

Publisher's Note Springer Nature remains neutral with regard to jurisdictional claims in published maps and institutional affiliations. 